\title{
CONFERENCE REPORT: 2ND ANNUAL CONFERENCE OF THE CENTRAL AND EASTERN EUROPEAN NETWORK OF LEGAL SCHOLARS (CEENELS): “AN UNEASY LEGACY: REMNANTS OF SOCIALIST LEGAL AND Political THINKING IN CENTRAL AND EASTERN EUROPE", JAGIELLONIAN UNIVERSITY, FACULTY OF LAW AND ADMINISTRATION, 7-8 JANUARY 2017
}

\author{
WOJCIECH ZOMERSKI*
}

On 7-8 January 2017 the Jagiellonian University Faculty of Law and Administration hosted the 2nd Annual Conference of the Central and Eastern European Network of Legal Scholars (CEENELS) convened by Mgr. Piotr Eckhardt (Jagiellonian University), Dr. Jacek Malczewski (Jagiellonian University), Dr. Rafał Mańko (University of Amsterdam), Dr. Michał Paździora (Centre for Legal Education and Social Theory (CLEST), University of Wrocław), Mgr. Michał Stambulski (CLEST, University of Wrocław). The conference was hosted by the Department of History of Political and Legal Thought, Jagiellonian University in collaboration with (CLEST), University of Wrocław. The Central and Eastern European Network of Legal Scholars (CEENELS) is an informal network of academic lawyers from the region. It was established in April 2015 in Brno at its inaugural 1st Annual Conference devoted to "25 years After the Transformation: Law and Legal Culture in Central Europe Between Continuity and Discontinuity". The aim of CEENELS is to provide a platform of multilateral cooperation between scholars from Central and Eastern Europe, including the Balkans, by organizing conferences, workshops, running a website and mailing list, as well as helping scholars

\footnotetext{
DOI: 10.1515/wrlae-2018-0019

* Master of Laws (University of Wrocław), Junior Researcher, Centre for Legal Educations and Social Theory, Wrocław; Candidate, Department of Legal Theory and Philosophy of Law, Faculty of Law and Administration, University of Wrocław. ${ }^{1}$ Wojciech Zomerski, 'Conference Report: 1st International Conference of the Central [and Eastern] European Network of Legal Scholars (CE[E]NELS) on "25 Years After The Transformation: Law And Legal Culture In Central And Eastern Europe. Between Continuity And Discontinuity", Masaryk University, Brno, Czech Republic, 16- 17 April 2015' (2014) 4.1 Wrocław Review of Law, Administration and Economics 103.
} 
from the region find partners for international research projects ${ }^{2}$. The topic of this year's CEENELS conference was "An Uneasy Legacy: Remnants of Socialist Legal and Political Thinking in Central and Eastern Europe". The organizers intended to study the "uneasy legacy" of the socialist period both in legal and political culture in our region and especially invited contributions in the form of case studies regarding the on-going impact of actually existing socialism/communism in different countries of the region.

The conference gathered together almost forty scholars from seven CEE countries (Bosnia and Herzegovina, Czech Republic, Hungary, Latvia, Lithuania, Romania and Poland). On 7th January, the conference was opened by Dr. Rafał Mańko who warmly welcomed all participants of the Conference and presented the idea of CEENELS, underlining the importance of strengthening the cooperation in the CEE region as opposed to only one-sided East-West cooperation, which unfortunately has been the rule until now. This was followed by the keynote debate devoted to "Rule of Law in Central and Eastern Europe - Between the Socialist Heritage and Illiberal Tendencies" moderated by adv. Michał Stambulski. Prof. Dr. hab. Tomasz Pietrzykowski (University of Silesia in Katowice), Prof. Dr. Mátyás Bencze (University of Debrecen) and Dr. Lucian Bojin (University of Timișoara) discussed the condition of the rule of law in Central Eastern Europe in the light of recent developments as well as historical legacies of actually existing socialis $\mathrm{m}$. The debate was followed by four parallel sessions, comprising a total of eight panels (with two-four presentations in each panel). Specific panels addressed issues of legal education, social memory, transitional justice, the condition of self-government, democracy and the rule of law, as well as examples of legal survivals (remnants) of the period of actually existing socialism in contemporary legal systems of the CEE countries.

On the second day of the Conference there were two parallel panels consisting of a total of five presentations. The issues discussed included restrictions on personal liberties in Poland in a historical perspective, adjudication in CEE, civilian awards and family allotments as examples of legal survivals of actually existing socialism, Andrzej Leder's notion of the dreamed-through revolution, the issue of communication in law, the crime of defamation and law and memory issues. The Conference was closed by the final plenary session moderated by Dr. Rafał Mańko. Doc. Martin Škop (Masaryk University, Brno, Czech Republic) delivered a paper devoted to "Lack of Discussion and Twilight of Legal Science". Professor Škop discussed legal science as limited and strongly influenced by the socialistic heritage, where open discussion and mutual criticism is rather suppressed in favour of false collegiality. In his paper he traced the reasons and context of this situation and exposed possible and covert mechanisms influencing the current shape of legal science in the Czech Republic. Dr. Cosmin Sebastian Cercel (Nottingham University) discussed the issue of "Socialist Law as Interregnum: On War, (Dis)Continuity and the End of State-Truth". The author discussed what socialism meant either as a matter of jurisprudential inquiry or as a matter of legal ideology. Dr. Cercel focused in his paper on the Romanian context, following constitutional and criminal law developments related to the communist takeover. Doc. Jānis Pleps

\footnotetext{
${ }^{2}$ For more details see: http://ceenels.org/info/about-ceenels/ [31.5.2018].
} 


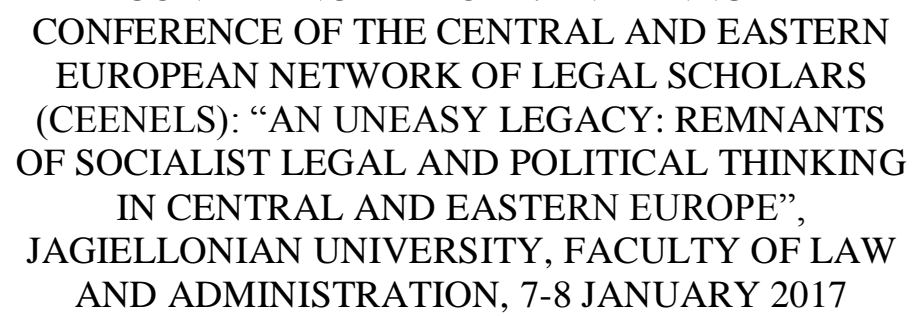

(University of Latvia) delivered a paper entitled "The socialistic heritage in the constitutional interpretation: case of Latvia". The author analyzed constitutional cases from times of democratic transformations to show the strong socialistic flavour of legal interpretation in Latvian jurisprudence which has remained despite the restoration of independence.

The Conference was followed by concluding remarks of organizers, Rafał Mańko and Michał Stambulski. They thanked all gathered scholars for coming to Kraków and invited them to the 3rd Annual Conference which will be hosted by the University of Latvia, Riga. Michał Stambulski expressed his special gratitude to Piotr Eckhardt whose effort and dedication made the conference a true success. 